\title{
Status of the Sondu-Miriu River fish species diversity and fisheries: Sondu-Miriu Hydro-Power Project (SMHPP) operations
}

\author{
Dickson Otieno Owiti ${ }^{1,3}$, Raphael Achola Kapiyo ${ }^{2}$ and Esna Kerubo Bosire ${ }^{2}$ \\ ${ }^{1}$ Department of Zoology, Maseno University, P.O Box 333-40105, Maseno, Kenya. \\ ${ }^{2}$ Department of Environmental Science, School of Environment and Earth Science, Maseno University, P.O Box 333- \\ 40105, Maseno, Kenya. \\ ${ }^{3}$ Department of Fisheries and Natural Resources, Maseno University, PO Box 333-40105, Maseno, Kenya.
}

Accepted 23 July, 2013

\begin{abstract}
The Sondu-Miriu Hydroelectric Power Project (SMHPP) is a run-of-the-river hydro-power project on the Sondu-Miriu River, Kenya. The part of the river studied: between the Sondu Bridge upstream, and Osodo Bay on L. Victoria, was divided into three zones; 1. Upstream of the dam, artificial lake approximately $5 \mathrm{~km}$ long; $15-2 \mathrm{~km}$ wide, 2. Depleted section and, 3. Lower section. SMHPP caused part of river below the dam (depleted section) to reduce in volume during power generation. Since inception, construction and implementation of the project, concerns were raised that the project would result in loss of Labeo and Synodontis fishes which were singled out as most vulnerable. This investigation set to determine the effects of SMHPP on river's fishes; and focused on species diversity, abundance and distribution. An electrofisher was used in sampling. The data obtained was compared with those reported earlier, particularly a single previous report based on electrofishing. Fish biomasses were: Upper zone 4,583 g, depleted zone, 10,666 $\mathrm{g}$ and lower zone, 22,004 $\mathrm{g}$ respectively, with a total biomass of $37,253 \mathrm{~g}$ from fishing activity lasting for $\mathbf{4 2 9} \mathrm{min}$. Catch-effort data for each zone; types, numbers and weights are given, compared and discussed. Diversity was highest, Simpson's Diversity Index was 12.945 in the upper zone.
\end{abstract}

Key words: Sondu-Miriu, hydropower project, electrofishing, fish diversity, river zones, fishing.

\section{INTRODUCTION}

From the inception of the ideas and feasibility activities of the Sondu-Miriu Hydroelectric Power Project (SMHPP) in Western part of Kenya, Lake Victoria Region of East Africa, the community of the Sondu-Miriu River area raised a number of concerns with the fear that the project would affect the local environment adversely in certain ways. High among this concern, was a possible negative effect on the fish and fisheries activities associated with the river. Although, the residents were divided in their complaints and the complaints were variously described as petty (Ouma, 2009), such concerns persisted (Ashe et al., 2009). According to Ashe et al. (2009), one of the complaints was that the community members had suffered loss of most sought after local fishes such as Labeo spp. and Synodontis spp. According to the community of the area, these fish species, (Labeo and Synodontis), were once abundant in the river unlike presently that they have become scarce. This scarcity has been caused by untreated waters released back to the river after running the turbines at the SMHPP Power 
House. Willoughby et al. (2003) and Kapiyo et al. (2003) had investigated and reported on the status of the fisheries and socioeconomic activities of the area to coincide with the initial stages of the SMHPP construction. The SMHPP was commissioned in July 2009 and soon after, it became operational. However, continued social and public protests and upheavals over the socioeconomics and environmental impacts by the project on the river fisheries, called for explanations based on properly carried out research and analyzed data. The present research was undertaken to provide information based on facts to both the locals and the international forums conscious of fisheries and environmental issues. The investigations aimed at determining the changes, if any, that occurred in the various aspects of the fisheries of the Sondu-Miriu River, particularly fish biodiversity, abundance and distribution which could be associated with the establishment and operations of SMHPP. Such information would benefit the SMHPP project contractors, and implementers, who "would be in the know" concerning the past and present status of fish and fishery of the SonduMiriu River. The studies were conducted during the March-April 2010 period.

\section{Sondu-Miriu and other Western Kenya Rivers fisheries}

Documented information on Sondu-Miriu River fisheries is scanty, and such information is almost non existence for the river upstream of Odino Falls. The scarce literature available addresses mainly the Lower Zone of the river up to Odino Falls, $10 \mathrm{~km}$ river course from the river mouth upstream. The available literature is also at variance with each other concerning the dominance and abundance of the fish species involved. However, from this scanty literature, it is noted that the Lower portion of the river and its floodplain has supported fisheries activities for a long period of time.

Amongst the first documented information on the Sondu-Miriu River fishery is that of Whitehead (1959) who reported that the most important migrant fishes of Sondu-Miriu River were as follows: the large barbusBarbus altianalis radicliffi (fuani), Labeo victorianus (ningu), Schilbe mystus (sire) and Tilapia vaiabilis (Mbiru). Other less abundant species according to White head (1959) were; Alestes- (Brycinus) (osoga), Synodontis spp. (okoko), Clarias (mumi) Bagrus (sewu) and Protopterus (kamongo). Later, Manyala and Ochumba (1992, 2008) found that the five most important species in the lower Sondu-Miriu were Schilbe mystus, Clarias gariepinus, Synodontis afrofischeri, Lates niloticus and Oreochromis variabilis. Later, Muli and Ojwang (1998) reported that the most abundant species in the lower part of the river were Schilbe mystus, Synodontis victoriae, Synodontis afrofischeri, L. niloticus and Labeo victorianus. According to Gichuki et al. (2001), Clarias gariepinus, Protopterus aethiopicus, Schilbe intermedicus, L. victorianus, Oreochromisniloticus, Synodontis victoriaeand Xenoclarias eupogon were the most dominant species in the same lower part of Sondu-Miriu River.

Indeed, many reports on the Sondu-Miriu River fisheries are concerned mainly with the lower part of the river, from the river's mouth up to the Odino Falls. Muli and Ojwang (1996) and Ochumba and Manyala (1992) had noted a significant decline of fish population in SonduMiriu River. Some researchers had reported on the general decline in river fisheries within the Lake Victoria basin including the Sondu-Miriu River. These reports include Cadwalladr (1964, 1965, 1969), Whitehead (1958, 1959), Kibaara (1981) and Awange and Ong'ang'a (2006).

Ochumba and Manyala (1992) noted that fish yield in the Sondu-Miriu River had decreased from 668 tons in 1959 to 108 tons in 1992; and that species such as Clarias gariepinus, Schilbe mystus and $S$. afrofischeri had replaced the more favorite traditional fisheries that had hitherto been dominated by Barbus altianalis and $L$. victorianus. Ochumba and Manyala (1992) and Willoughby (2006) had independently recommended fish species transfers and re-stocking of the river as a management measure in reviving the river fisheries. Fish relocation was later undertaken by Willoughby (2003), when 350 individuals of a mixture of $L$. victorianus and the large barbus ( $B$. altianalis) were transferred into the depleted zone between the downstream of the Apoko dam and the upstream of the Odino Falls.

Like the other rivers of Lake Victoria Basin such as Nzoia, Nyando, Yala, Mara and the others. Particularly, the Lower part of the Sondu-Miriu River fisheries must have played important role as source of fish for the riparian community in the first half of the last century. But the significant river fisheries as an important source of fish for the local people gradually waned as a result of reducing fish stocks.

The reasons for the decreased fish populations in the rivers are varied and include increased fishing intensity and pressure and poor fishing methods, as well as the effects of climate change with changes in water quality and erratic river flow regimes. For the case of the SonduMiriu River, Mainga (1981) noted that river pollution by the agric-based chemicals washed down into the river by surface runoffs caused by the decline in fish stocks. The decline in the catches of such species such as Labeo, Alestes (Brycinus) and the Barbus species had been attributed to predation by the Nile perch and intensive fishing that include use of prohibited gears (Manyala and Ochumba, 1990). Mwashote and Shimbira (1994) also noted that agricultural practices that are accompanied by use of agrobased chemicals played a big role in the decline of fish in the Sondu-Miriu River. Witehead (1959), Ochumba and Manyala (1992), Ogutu-Ohwayo (1990) and Muli (1990) stated that the main causes of decline in the catches of riverine species in the region include over- 


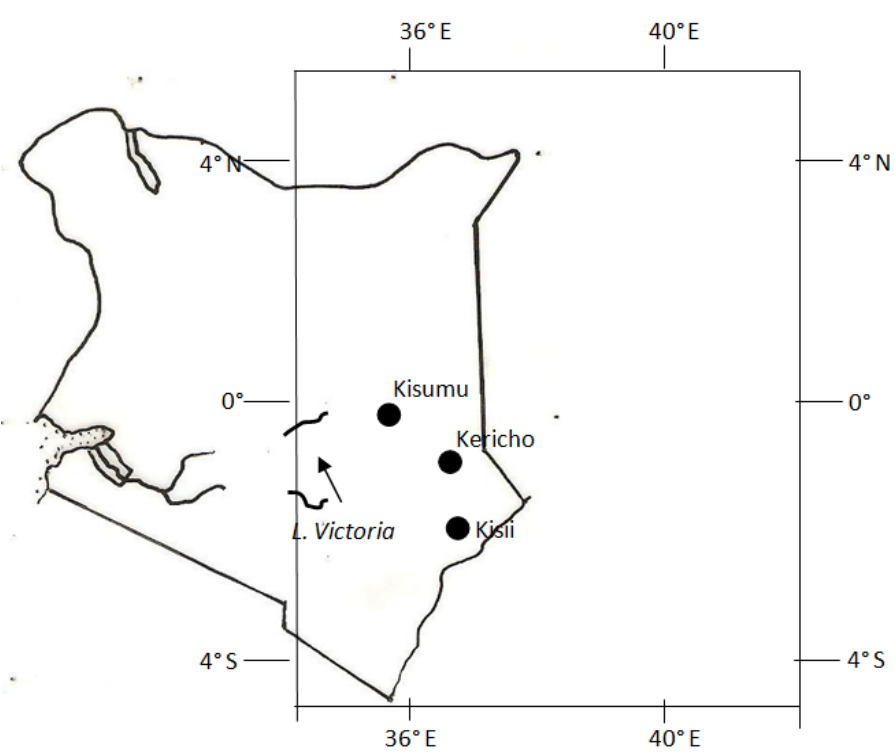

Figure 1. Map of Kenya showing the position of the Sondu-Miriu River and the portion of the river in the present study.

fishing, use of destructive fishing methods, habitat destruction, poor fisheries management and pollution.

Various fishing methods are used to catch fish in the Sondu-Miriu River. These include the use of gill-nets, barrier traps, long lines (hooks and rods), seine nets and mosquito nets. The use of the various traditional fishing baskets known by the locals as sienyo, ounga and traps are becoming rare. Also, traditional spear fishing is fading away. The main fisher folk are males, both the adults and the youth. In the past, women used to fish using baskets, but this has since faded away. Only two previous studies (Willoughby et al., 2003 and Kapiyo et al., 2003), of the Sondu-Miriu River have so far include the upstream of the Odino Falls; and in the course of these studies, the river course about $40 \mathrm{~km}$ from the Sondu Bridge to the river mouth had been categorized into the three zones; upper, middle and lower zones.

\section{MATERIALS AND METHODS}

\section{Study area and the Sondu-Miriu River}

The study area is depicted in Figures 1 and 2. The Sondu-Miriu River is one of the several main rivers that feed Lake Victoria on the Kenyan side of the lake; the Nyanza Gulf. It is one of the five major rivers of the Kenya's Lake Victoria, basin; the others are Nzoia, Yala, Migori-Kuja, and the Nyando Rivers. As shown in Figure 1, Sondu-Miriu has its source on the western slope of the Mau Escarpments of Kenya with approximately $3,470 \mathrm{~km}^{2}$ of catchment area of the highlands within and adjacent to western part of Kenya. In its lower course, the river flows through narrow gorges in the southern escapements of the Nyakach plateau; it then meanders into the Odino Falls and to the flood-plains of Nyakwere and Sango as it pours its waters into the Lake Victoria at the Osodo Bay.
The Odino Falls on the river is a major and the most conspicuous and significant physical feature on the Sondu-Miriu River course. The falls are located in the Nyakach plateau and the escapement. The Odino (locally called barrier) falls (Figure 2), situated $10 \mathrm{~km}$ upstream of the Sondu-Miriu River mouth, actually forms an effective barrier on the path of upstream migration for any aquatic organisms, particularly fishes that might attempt to take such migrations.

A significant portion of the Sondu-Miriu River waters is, dammed and diverted for use in the generation of hydroelectric power by the Sondu-Miriu Hydroelectric Power Project (Figure 2). The SMHPP power house is located at Kolweny, approximately $400 \mathrm{~km}$ from Kenya's capital, Nairobi. The water is dammed and diverted from the river at Apoko, and directed via underground tunnel (Figure 2) to the Power House, approximately $10 \mathrm{~km}$ from the river. The dam at Apoko has created an artificial lake in the upstream of the river (Figure 2). The name of the newly created lake varies from Lake Apoko to Pond Area.

The studied portion of the river (Figure 1) was divided into three sections as described below:

1. Upper zone (UZ) which partly contains the pond area (the newly created artificial lake), the impoundment zone and the river course upstream of the lake to Sondu Bridge. The Upper Zone has been identified in 5 sites (Table 1)

2. Depleted zone (DZ) where much water is intermittently withdrawn to run the turbines of the SMHP project at Kolweny, approximately $10 \mathrm{~km}$ away from the dam intake, Depleted Zone has been identified in 6 sites (Table 1)

3. Lower zone (LZ) part of the river into which the water from the turbines renters the river and continue to flow down to the lake. Lower Zone has been identified in 9 sites (Table 1)

In the present study, a total of twenty sampling sites, each corresponding to those that had been sampled in the previous (Willoughby et al., 2003) electro-fishing method was used.

\section{Fishing}

Eletro-fishing (Figures 3 and 4) was adopted as the preferred fishing method and this technique had been successfully used by the previous (Willoughby et al., 2003) survey. Twenty stations were sampled along the five stretches (zones) of the river.

For each site, a span of $50 \mathrm{~m}$ on either side of the generator and giving a 100 meter stretch of the sampling site. The electrofisher used was a Variable Voltage Pulsator Electro-Shocker Model VVP15 equipment with a generator machine, producing direct current at $400 \mathrm{~V}$ and $10 \mathrm{~A}$; an anode of a $30 \mathrm{~cm}$ ring attached by $50 \mathrm{~m}$ of heavy cable to the control box and a cathode of $2 \mathrm{~m}$ of splayed copper cable. The system was operated by trained and experienced technicians. The time taken for electro-fishing activity at each sampling site was from 14 to $43 \mathrm{~min}$. Each fish caught was identified to species using field guides of fishes of East Africa and of the Lake Victoria region (Greenwood, 1966; Whitehead, 1959).

The average fishing activity (approximately $22 \mathrm{~min}$ ) resulted in a catch rate of $87 \mathrm{~g}$ of fish per minute. This compares closely with that of Willoughby et al. (2003), of average fishing activity of approximately 23 min with catch rate of $53 \mathrm{~g}$ of fish per minute.

Length-frequency distribution and length-weight data for each sampling site were recorded. The observed data were compared with the information gathered from the local fishermen, administrative personnel and local residents; and with the available documented reports from previous investigations. The catches from the various zones were compared to show distribution, variety and abundance along the Sondu-Miriu riverine fisheries; and this fishery sub-sector's contributes to the general well being of the riparian populations of the study area. 


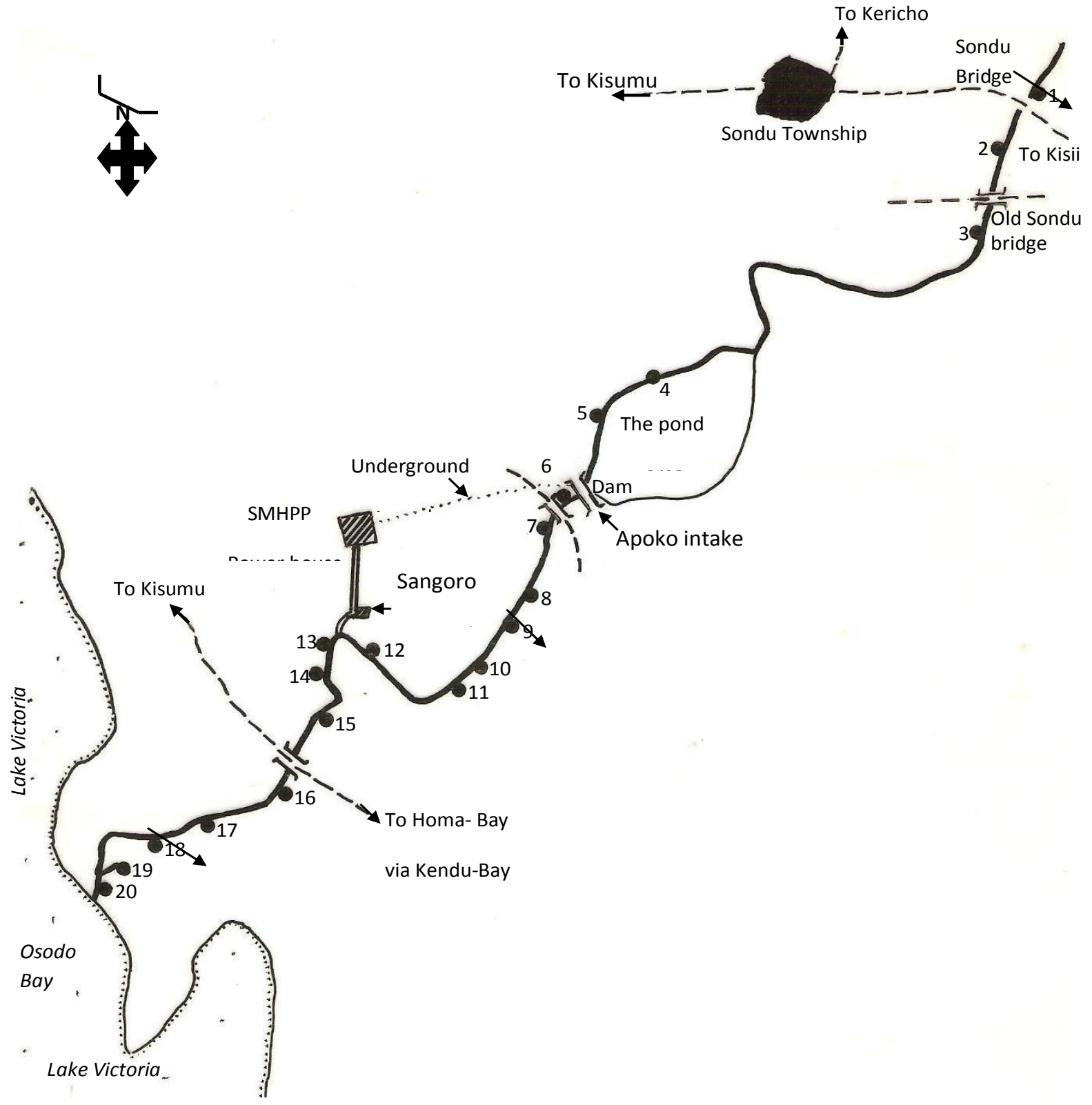

Figure 2. Sampling sites by numbers of the Sondu-Miriu River. This is a longitudinal section of the river from the Sondu-Bridge in the upstream to the river's mouth at Osodo Bay on Lake Victoria.

Table 1. Sampling sites identified in each zone of the studied river and named accordingly.

\begin{tabular}{|c|c|c|}
\hline Upper zone (5 sites) & Depleted zone & Lower zone (9 sites) \\
\hline 1) Sondu Bridge & 6) Intake Bridge & 12) Wadhlango Rapids \\
\hline 2) Sondu Gauge & 7) Intake Downstream & 13) Wadhlango Beach \\
\hline 3) Sondu Old Bridge & 8) Kut Pool & 14) Sang'oro Gauge \\
\hline 4) Mamboleo Gauge & 9) Kut Pool Downstream & 15) Asera Oyster Bed \\
\hline \multirow[t]{5}{*}{ 5) Mamboleo Downstream } & 10) Kuoyo Sand Site Up & 16) Nyakwere Bridge \\
\hline & 11) Kuoyo Sand Site Down & 17) Nyamnacha Banks \\
\hline & & 18) Nyandho Ferry \\
\hline & & 19) Chuowe Stream \\
\hline & & 20) Osodo Beach \\
\hline
\end{tabular}




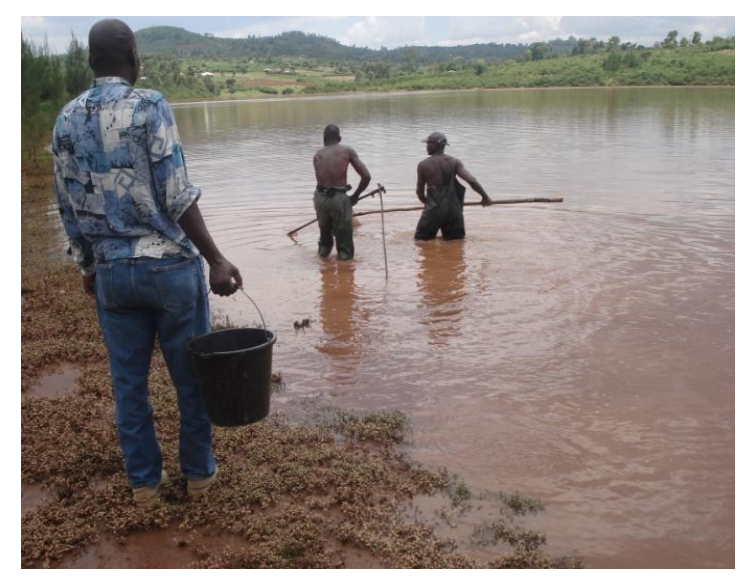

Figure 3. Electrofishing in progress in the pond area (the newly created artificial lake).

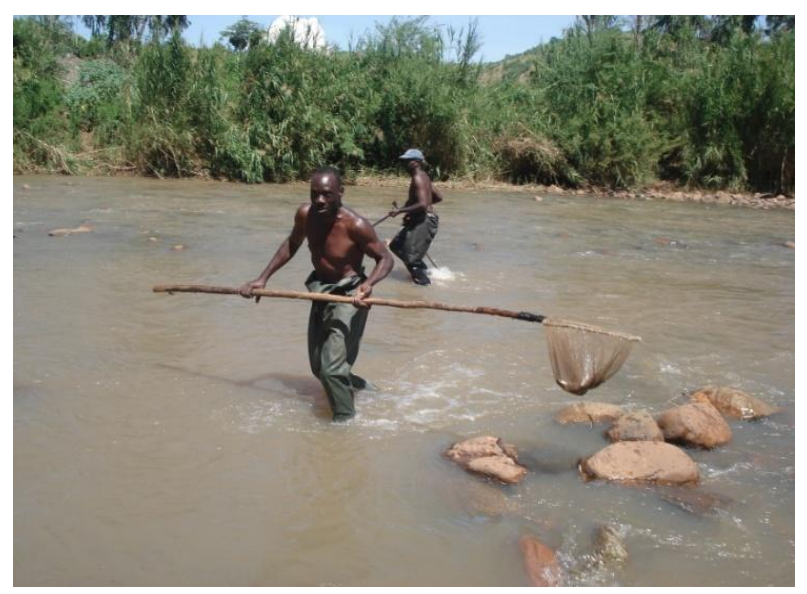

Figure 4. Bringing the catch ashore.

\section{RESULTS AND DISCUSSION}

Representatives of the fish caught are given on Table 2 . According to Reynolds (1983) it is appropriate and more meaningful to record catch rates by electrofishing in terms of weight $(\mathrm{g})$ per $100 \mathrm{~m}$ or per minute. A number of reporters have, however, reported their catch rates in terms of $\mathrm{kg} / \mathrm{h}$ or $\mathrm{kg} / \mathrm{km}$. It was noted in the present study that the electrofishing in Sondu-Miriu River was more convenient to report the catches in terms of weight $(\mathrm{g})$ per minute or weight $(\mathrm{g})$ per $100 \mathrm{~m}$.

During the present survey, a total of 25 species were caught in the river (Table 2). A number of reports have variously reported the number of fish species in the Sondu-Miriu River at between 14 and 30 species. Some of these reports include that of Whitehead (1959), 14 species; Willoughby (2006), 24 species; Manyala and Gichuki (1992), 30 species; Mugo and Twaddle (1999), 18 species; and Gichuki et al. (2001), 28 species. Many of these reports are for the lower portion of the river (from river-mouth to Odino Falls) only.

Comparison in the present electrofishing survey was made with that of the previous survey (Willoughby et al., 2003) and the following species; which had been reported by Willoughby et al (2003) were: Protopterus aethiopicus, Bagrus docmack, Brycinus salderi; from the Lower Zone of the river and Xystichromis spp. reported from the Upper Zone. Conversely, the following species which were captured during the present survey were absent from the previous (2003) survey; Synodontis victoriae and Schilbe mystus (Lower Zone) and Haplochromine species which were caught in the various zones of the river. Other species such as Mormyrus (Mormyridae), and black bass Macropterus salmoides which have been frequently reported from the Sondu-Miriu River by some other workers were not caught; neither during the present nor in the previous electrofishing surveys.

\section{Species diversity}

Catch-effort data collected were used to determine the diversity indices for each of the three zones. Simpson's Diversity Index was highest (12.945) in the Upper Zone.

The main fishes of Sondu-Miriu caught during the present survey ranked in order of biomass (total weights landed): B. altianalis, L. victorianus, C. gariepinus, S.e mystus, $O$. leucostictus, $O$. variabilis, $T$. rendalii, L. niloticus and $C$. theodorei.

Each of the three "traditional zones" of the river is well described in the present as well as by the two earlier reports (Willoughby et al., 2003; Kapiyo et al., 2003). However, on the establishment of the SMHPP and it becoming operational, five zones of the area are now evident, and there are clear deviations from the "traditional" three zones. The five zones as per the present study, and which are hereby recommended for any future studies are depicted on Table 1 and Figure 2. These suggested that new zones are represented by the sampling sites as follows:

1. Upstream Zone: sampling sites 1, 2 and 3.

2. Pond Area Zone: sampling sites 4 and 5.

3. Depleted Zone up of Odino Falls: sampling sites 6, 7, $8,9,10$ and 11

4. Depleted Zone Down of Odino Falls: sampling sites 12 and 13.

5. Lower Zone: sampling sites 14, 15, 16, 17, 18, 19 and 20.

These newly created zones can be designated as Zones I-V, described as follows:

Zone I: Upstream of the newly created lake. This is part of the river between Sondu-Bridge and the upper reaches (or upstream-end) of the lake created by the dam at Apoko (Figure 2). 
Table 2. Inventory of fishes of the Sondu-Miriu River, a result from the electrofishing survey (2010).

\begin{tabular}{lll}
\hline Scientific names (Species) & Common name (English) & Local name (Luo) \\
\hline Barbus altianalis & Large barb & Fuani \\
B. jacksonii & Three spot barb & Adel \\
B. appleugramma & Small barb & Adel \\
B. kestenii & Orange cheecked barb & Adel \\
B. neumayeri & Neumayer's barb & Adel \\
B. nyanzae & Nyanza barb & Adel \\
B. paludinosis & Pallid barb & Adel \\
Labeo victorianus & River carp & Ningu \\
Rastrineobola agentae & Sardine & Omena \\
Clarias alluaudi & Catfish & Nyapus \\
C. gariepinus & Catfish & Mumi \\
C. theodorei & Catfish & Ndhira \\
Synodontis afrofischeri & Squeaker & Okoko rateng \\
S. victoriae & Squeaker & Okoko rachar \\
Schilbe mystus & - & Sire \\
Apploccheilichthyes bukobanus & Mosquito fish & - \\
Mastacembelus franatus & Spiny eel /Freswater eel & Luri/Okunga \\
Lates niloticus & Nile perch & Mbuta \\
Astatoreochromis alluaudi & Haplo & Fulu \\
Oreochromis niloticus & Tilapia & Ngege / Nyamami \\
O. leucostictus & Tilapia & Opat/Ngege \\
O. variabilis & Tilapia & Mbiru/Ngege \\
Pseudocrenilubras multicolor & Haplo & Fulu \\
Tilapia rendallii & Tilapia & Opat/Ngege \\
T. zillii & & Silisili/Ngege \\
Haplochromine sp. & Haplo & Fulu \\
\hline & & \\
& &
\end{tabular}

Zone II: The Pond Area (Apoko Lake) that holds the dammed waters accumulating upstream of dam.

Zone III: The Depleted Zone from the Apoko dam downstream to the Odino Falls.

Zone IV: The continued Depleted Zone from the base of Odino Falls down-stream to the Sang'oro Re-entry of outlet. This is the section of the river between the OdinoFalls and the outlet adjacent to "the presently constructed Sang'oro Hydroelectric Power Project (SHPP).

Zone V: The Lower Zone. This is the section of the river from Sang'oro Re-entry of outlet to the river mouth on the Lake Victoria's shores at Osodo-Bay.

It is noted that in the present study, Zones I and II coincide with the Upper Zone (UZ) of Willoughby et al. (2003) and Kapiyo et al. (2003). Depleted Zone (DZ) of Willoughby et al. (2003) coincides with the present Zone III. Lower Zone (LZ) by the earlier authors is presently represented by Zones IV and V. The number of sites sampled in each zone and their descriptions are given in Table 2. The sampling sites, except sites 4 and 5 in UZ were, however, identical to those of Willoughby et al. (2003). It is particularly noted that in the 2003 studies, the present Zone II sampling sites were riverine, while in the present study, these sites are the near shore waters of a lacustrine ecosystem of the newly created artificial lake. The two sites are thus proximate but not identical to those sampled previously (in 2003).

\section{Conclusion}

Although, river fisheries in the Lake Basin of Kenya have reported decline in the recent past, the present results reveal increase in the abundance of fish for the case of the Sondu-Miriu River. The relations between this positive occurrence and the SMHPP is evidently due to new hydrological factors that have resulted in five distinct river zones each with unique characteristics. The five zones emerged out of the traditional three zones due to damming of the river by the SMHPP. A new fishery based on lacustrine ecosystem has been created. Besides this, it should be noted, also, that technology can "emancipate" nature by waking up its forces (Kluxen, 1994). In the present case, there is evidence that the establishment of SMHPP resulted in the upsurge in fish abundance in the Sondu-Miriu River.

Fish has become more abundant. The questions to ask now may be about sustenance, conservation and further improvement on the abundance. These results are contrary to the Sondu-Miriu riparian community's claim that 


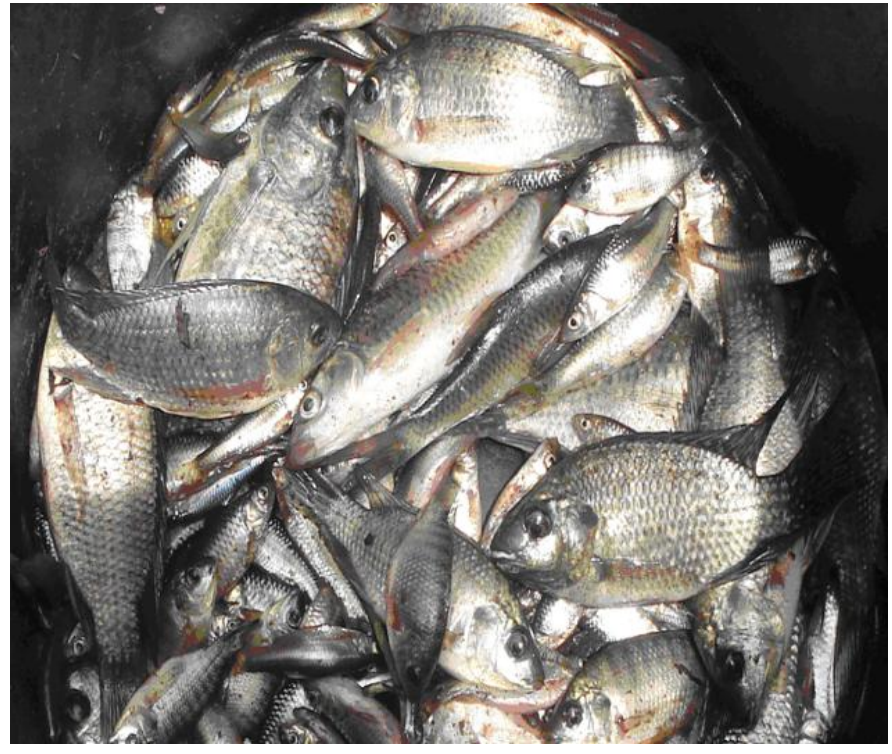

Figure 5. Different sizes of tilapia fish caught by beach seining at the newly created artificial Apoko Lake of the Sondu-Miriu River.

this part of the river (UZ and DZ) has no fish. The community seems ignorant of the present and abundant fish in this part of the river. It is noted, also, that in spite of the newly created and promising fisheries that has, apparently occur due to the creation of a new lake in the area (Lake Apoko/ the Apoko Pond area in the Upper Zone), there are already uncontrolled and destructive irresponsible methods of fish harvesting going on in the area (Figure 5).

The beach seining activities with the use of wrong and unauthorized gears that include the use of mosquito nets destroy even the young fish (Figure 5). According to one fisherman and a key informant interviewed during the present study, "the beach seines used here destroy even the eggs and the new spawn". This irresponsible overexploitation of a fishery must be stopped, but this can only be an enormous challenge to authorities given the poor understanding, misconceptions and the miscommunications among the riparian community regarding fishes in their sections of the river and the effects of the establishment and operations of the SMHPP.

Although, river fisheries in the Lake Basin region has been declining rapidly, the outcry by the Sondu-Miriu River Riparian Community concerning the loss of the river fish cannot be substantiated. The claim on loss of fish stocks from the river seem to be based on lack of information on this river fishery. The present results of the scientific survey reveal increase in the abundance of fish in the river, contrary, also to the current general trend of fish decline in many rivers.

The possible reasons for increased fish abundance in the Sondu-Miriu River may be due to the following reasons:

\section{Reduced predation from the Nile perch}

2. NEMA activities which has created awareness against polluting the river by agrochemicals.

3. Since many important riverine species are actually potamodromous, migrating from the lake to the river, the water hyacinth, Eichhornia crassipes which has plagued Lake Victoria, particularly parts of the lake adjacent to this river's mouth, has afforded these prey fish protections from the Nile perch predation. When the fish are still within the lake, prior to taking the migration into the rivers they are under cover of the water hyacinth. Increased fish populations are thus available at areas of the lake adjacent to the river mouth at the onset of the migration process to the river. This translates to the current increase in the abundance of fish in the SonduMiriu River;

4. The creation of the artificial Apoko Lake above the SMHPP intake Dam at Apoko has provided fish with a conducive environment (the lacustrine ecosystem) in which to live and multiply;

5. The reduced water level in the depleted area made the catching of fish easier during low water levels.

\section{ACKNOWLEDGEMENTS}

The Kenya Marine and Fisheries Research Institute, Kisumu provided the "Set of Elecrofisher Equipment" and the technical staff to operate them. The Kenya Electricity Generating Company (Ken Gen) provided suitable means of transportation by which the sampling sites along the river were accessed.

\section{REFERENCES}

Ashe B, Greef L, Haya B, Obbo B (2009). The Information Relevant to the Validation of the Sondu- Miriu Hydroproject, Kenya Memo to DNV on CDM Validation for Sondu_Miriu Large-Hydro Kenya, September 11, 2007: Current Status; Negative as of August 2009 International Rivers, People, Water, Life.

Awange JC, Ong'ang'a O (2006). Lake Victoria, Ecology, Resources, Environment Springer, Berlin. p 347.

Cadwalladr DA (1964). An account of a decline of Labeo victorianus Boulenger fishery of Lake Victoria and an associated deterioration of indigenous fishing methods in the Nzoia River, Kenya E Afr. Agr. For. J. 30:245-256.

Cadwalladr DA (1965). Notes on the breeding biology and ecology of Labeo victorianus Boulenger (Pisces: Cyprinidae) of Lake Victoria Rev Zoo. Bot. Afr. 72(1-2):109-134.

Cadwalladr DA (1969). A discussion of possible management methods to revive the Labeo victorianus fishery of Lake Victoria with special reference to Nzoia River, Kenya Uganda Fisheries Department Occasional Paper 2.

Gichuki J, Dahdohuh GF, Mugo J, Rabuor CO, Triest L, Dehairs F (2001). Species inventory and the local uses of the plants and fishes of the Lower Sondu-Miriu wetland of Lake Victoria Hydrobiologia 458: PDF (7282 KB) Free Preview ISSN 00188158 (Print) pp.1573-5117.

Gichuki N (2006). Wetland research in Lake Victoria basin, Kenya part Analysis and synthesis report www.iucea.org

Kapiyo RK, Kibwage JJ, Abila RO (2003). The status of fisheries and fishing activities of the Sondu-Miriu River Technical Report to KenGen / KOEI LTD Japan. 
Kibaara D (1981). Endangered fish species of Kenya's inland waters with emphasis on the Labeo spp In Proceedings of the workshop of the Kenya Marine and Fisheries Research Institute on Aquatic Resources of Kenya Mombasa, Kenya pp.157-164.

Kluxen W (1994). Philosophical aspects of interplay between nature and artificial environment of man. In Odera Oruka (Ed) Philosophy, human and ecology. Philosophy of Nature and Environmental Ethics. ACTS Press, Nairobi African Academy of Sciences pp 98-106.

Mainga OM (1981). Some hydrobiological conservation at the mouths of two affluents rivers of lake Victoria with special emphasis on Synodontis. MSc Thesis University of Nairobi.

Manyala JO, Ochumba PBO (1990). Small scale fishery of lower Sondu-Miriu River In the proceedings of the symposium on swocioeconomics aspects of Lake Victoria Fisheries IFIP Project Symposium, CIFA sub-committee for Lake Victoria April 25-27, Kisumu, Kenya.

Muli JR (1998). An appraisal of stochking and introduction of fish in Lake Victoria (East Africa). In IG Cowx (Ed), Fishing News Books Blackwell Science Ltd. pp.258-266.

Mwashote BM, Shimbira W (1994). Some limnological characteristics of the lower Sondu-Miriu River, Kenya. In recent trends of research on Lake Victoria Fisheries. Proceedings of the second EEC Regional Seminar on recent trends of research on Lake Victoria Fisheries $25^{\text {th }}-27^{\text {th }}$ Sept 1991 , Kisumu, Kenya Eds E Okemwa, EO Wakwabi and Getabu A ICIPE Science Press.

Ochumba PBO, Manyala JO (2008). A description of the fisheries of the Lower Sondu-Miriu River before the construction of the SMHPP Aquaculture Research 23:701-719 Published on line $21^{\text {st }}$ April 2008 Journal Compilation (C) 2010 Blackwell Publishing Limited.

http://www3interscienceWilleycom/journal/119337227/Abstract?
Ochumba PBO (1994). Conservation plans for Lake Victoria Magazine of East African Wildlife Society March/April 17:36.

Reynolds JB (1983). Electrofishing In Nielsen, L A \& Johnson D L (eds) Fisheries Techniques American Fisheries Society Blacksburg, Virginia ISBN 0-913235-00-8. pp.147-163.

Whitehead PJP (1958). Indigenous river fishing methods in Kenya E Afr. Agr. For. J. 24:111.

Whitehead PJP (1959). The anadromous fishes of Lake Victoria Victoria Rev. Zoo. Bot. Afr. 59:329-263.

Wikipedia Free Encyclopedia (2010). Economy of Kenya CIA World Fact Book, Wikimedia Foundation; last modified, $11^{\text {th }}$ February 2010.

Willoughby NG (2006). Fisheries and ecology of Sondu Miriu river, Western Kenya. www.thenrgroup.net/theme/Sondu/sondufish.htm

Willoughby NG, Kapiyo R, Mugo J, Owiti D (2003). The implication of the Sondu Miriu Hydropower project (Kenya) for fisheries and fishing communities. The Land 7(1):3-20. 